\title{
The Effect of Brand Image, Website Quality, and Trust Towards Customer Loyalty in the Indonesian Consumer-to-Consumer (C2C) E-Commerce Business
}

\author{
Nicholas Wilson ${ }^{1 *}$ \\ ${ }^{1}$ Department of Management, Faculty of Social Sciences and Humanities, Universitas Bunda Mulia, Indonesia \\ *Corresponding Author. Email: wp8989@yahoo.com
}

\begin{abstract}
This study was commenced to understand the effect of brand image, website quality, and trust on loyalty in the Consumer-to-Consumer (C2C) E-Commerce business in Indonesia. This study used a survey method with the questionnaire as an instrument to gather the data required. As many as 350 respondents participated in this study, whereas all data was collected from those living in Jakarta. A total of 350 questionnaires were equally and virtually distributed to each respondent, in which, after further examinations, 323 questionnaires were deemed valid and usable. All data was then further processed and analysed using PLS-SEM method. After analysing all the acquired data, it can be concluded that brand image, website quality, and trust positively affect customer loyalty in the $\mathrm{C} 2 \mathrm{C}$ e-commerce business in Indonesia, in which, website quality revealed to have a stronger role in affecting customer loyalty relative to the other two variables due to the higher t-value possessed by website quality. Furthermore, it was revealed that trust mediates the effect of brand image and website quality on customer loyalty in this business sector.
\end{abstract}

Keywords: Brand Image, Website Quality, Trust, Customer Loyalty, Indonesian C2C E-Commerce Business

\section{INTRODUCTION}

E-Commerce has been determined and considered as one of the most-developed business sectors in the world. Furthermore, several authors have also suggested and stated that compared to other sectors, such as the automotive, healthcare, and smartphone business, the ecommerce stands out as one of the most promising and highly-developed sectors not only in the world, but also in Asia and Indonesia due to its constantly-increasing growth-rate and the rapid increase of market value of each company within the industry [19] [24]. Moreover, ecommerce has also been classified as one out of ten most promising industries for people or investors to invest their money in [6].

The rapid increase in popularity, growth, and penetration rate of the e-commerce business, does not only occur in Indonesia and Asia, but also occur all over the world, which could be attributed to the fact that the emergence of e-commerce has revolutionized the way people are conducting their business, or buying things. From the sellers' perspective, thanks to the emergence of ecommerce, because every single person in this planet could just literally build their own online store through various $\mathrm{C} 2 \mathrm{C}$ e-commerce intermediaries, such as Alibaba, Tokopedia, Bukalapak, Shopee, or Amazon.com. Through these websites, users could create their own store without having to pay, thus reducing the significant amount of costs incurred to the process of establishing a business within this industry. On the other side, from the buyers' perspective, the emergence of e-commerce has also changed the landscape of their buying process, in which, thanks to it, buyers could just literally buy all the goods or services they want by visiting the online store they favour, and complete the transaction by means of virtual payment methods, and get their order approved by the seller while sitting on their couch, watching TV, or accessing Netflix at the same time. Therefore, at least it eliminates the time and transportation costs which usually will be incurred to the customers if they're conducting purchasing activities in a traditional way. Therefore, based on the descriptions above, it could be well understood as to why e-commerce has been emerged as one of the most promising, favoured, and most rapid-growing sector in Indonesia.

Customer loyalty has been determined by so many authors to be the main antecedents of success for all companies around the world, regardless of the business sector [1] [2] [3] [4] [8] [9] [15]. Defined as customers' own preference to re-buy or re-use the product or services sold or marketed by the same company, customer loyalty is an important variable which can determine the success or failure of a company in an industry [13] [18] [21] [23]. Therefore, it could be perfectly understood that a company can't sustain their current position in the market or industry, if they are unable to induce loyalty in consumers' mind [13] [18] [21] [23]. Furthermore, it was further understood and perceived that loyalty played a significant role in determining the company's success in the ecommerce business, as it would be incredibly easy for the customer to switch from one company to others if they feel 
that the service (and any other aspects) that the company offer to them failed to satisfy their needs. Therefore, it is incredibly important for the company to understand the importance of marketing in order to maximize the company's potential and helping them to improve their market share and position in the market [4] [17] [18].

Moreover, in terms of factors or variables which could possibly affect the level of loyalty that consumers have in their mind, it was also found out that both website quality and brand image could positively affect customer's level of trust and loyalty toward the company, product, service, or even brand [5] [17] [19] [22] [23]. Website quality could be defined and understood as the customers' or people's judgement toward the quality of the website that they're operating [22]. Meanwhile, brand image could be understood as people's perception regarding a product, service, company, or brand [20]. Trust itself could be defined as people's or consumers' willingness to conduct some or various transactional activities toward a company [23]. When people have a positive perception toward the company, while not encountering any problems or troubles during their time surfing or browsing the company's website, then it would be safe to assume that both factors will improve customers' trust toward the company. And as the time goes by, it would eventually improve customers' loyalty toward the company. Based on the explanation above, the author was interested to thoroughly examine the effect of brand image and website quality on customer loyalty, both in direct and indirect manners through the existence of trust, in the e-commerce business in Indonesia.

\section{LITERATURE REVIEW}

\subsection{Brand Image}

Brand image can be defined as consumers' personal perception regarding the company, whereas such a perception emerges due to the customers' past experiences toward the company [21]. Moreover, brand image can also be understood as consumers' judgement regarding all of the activities that the company or brand was conducting [20].

\subsection{Website Quality}

Website Quality could be defined as the overall quality possessed by a website, in which, the quality of the website could be assessed from the technical, visual, or navigational aspect of the website itself [23]. In ecommerce context, website quality has an significant role in mediating the relationship between the seller and the buyer, since in the e-commerce business, both the seller and the buyer don't directly communicate with each other. Instead, the interactions between both parties are mediated by a website, in which through this website, both parties could establish and maintain a good interaction and communication with each other [19].

\subsection{Trust}

Trust could be defined as a state or condition in which customers are willing to interact and engage in the communication and transactional process with the company [14]. Furthermore, Trust could also be understood as a state or condition in which customers are dare or willing to take the risk during the transactional process with the company [16]. Furthermore, Trust can also be defined as consumers' willingness to participate and give their personal information to the company for the purpose of completing the transaction [23].

\subsection{Customer Loyalty}

Loyalty can be understood as customers' personal motivation and drive to re-purchase or re-buy any products or services offered by the same company in the future [1]. Furthermore, the concept of loyalty can also be perceived as the condition in which consumers are willing to re-visit, re-engage or re-communicate with the same company or provider in the future [2] [3].

\subsection{The Effect of Brand Image on Trust}

Preceding study concluded that brand image has a positive effect on trust. In this case, customers' trust toward the company tends to strengthen when they see the company's image to be positive or favourable [16]. Moreover, another research also found that customers' or people's perception toward the company's image could significantly affect trust that the customers have toward the company [14]. Therefore, in regards with the explanation above, the author would like to develop the hypothesis as follow:

\section{$\mathrm{H}_{1}$ : Brand Image has a positive effect on Trust.}

\subsection{The Effect of Website Quality on Trust}

Preceding study found that website quality positively affects trust in the e-commerce business, in which, the website's navigational, visual, and technical quality could shape and increase customers' level of trust in consumers' mind toward the company [21]. However, another research in China found the contrary, in which, in the Chinese ecommerce industry, website quality doesn't have a positive influence on trust [23]. In accordance with the previous literatures above, the author would like to develop the hypothesis as follow:

\section{$\mathrm{H}_{2}$ : Website Quality has a positive effect on Trust.}

\subsection{The Effect of Brand Image on Customer Loyalty}

Preceding research found that brand image has a significant effect on loyalty in the e-commerce business in Indonesia, in which, customers' level or sense of loyalty tend to strengthen as the image possessed by a company or 
brand is viewed as positive or favourable by the customers, and vice versa [18]. Moreover, another research also found that the image possessed by a company could have a positive impact on people's loyalty toward the company [12]. Therefore, in accordance with the explanation above, the next hypothesis could be developed as follow:

$\mathrm{H}_{3}$ : Brand Image has a positive effect on Customer Loyalty.

\subsection{The Effect of Website Quality on Customer Loyalty}

Preceding research found that there's a significant effect of website quality on customer loyalty, both in an indirect and direct manner, through trust as a mediating variable [21]. Moreover, another study also found that the quality of a website could determine people's or consumers' intention to re-purchase a product through the same site or providers [23]. In accordance with the literatures above, the fourth hypothesis could be developed as follow:

$H_{4}$ : Website Quality has a positive effect on Customer Loyalty.

\subsection{The Effect of Trust on Customer Loyalty}

Preceding studies found the importance of trust in affecting customer loyalty, or customer intention to repurchase the products from the same website [14] [16]. Furthermore, other studies also end-up with the same conclusions, in which, trust has a positive impact on customer loyalty or intention to re-buy the products from the same store or site, in which, trust has a positive effect on customers' intention to engage in further transactional activities with the same company in the future [5] [15] [19]. In accordance with the literatures above, the next hypothesis was developed as follow:

H$_{5}$ : Trust has a positive effect on Customer Loyalty.

\subsection{The Effect of Brand Image and Website Quality on Customer Loyalty through Trust}

Preceding study determined that trust significantly mediates the effect given by website quality on loyalty or repurchase intention [23]. Furthermore, another research conducted in Indonesia also found that trust partially mediates the effect of website quality on customer loyalty or repurchase intention [21]. In accordance with the literatures above, the next hypotheses could be developed as follows:

$H_{6}$ : Brand Image has a positive effect on Customer Loyalty through Trust as a mediating variable.

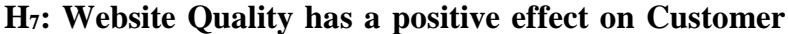
Loyalty through Trust as a mediating variable.

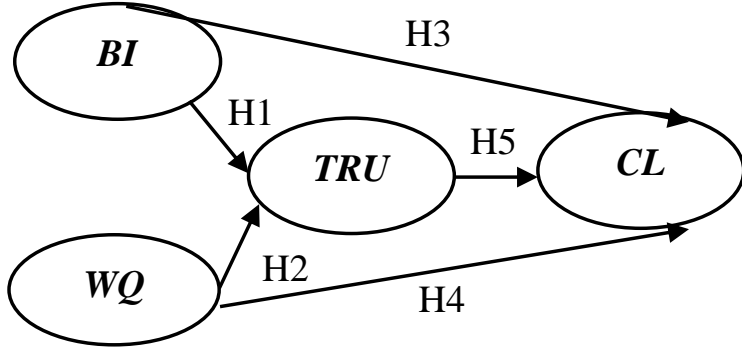

Figure 1 Research Framework

\section{RESEARCH METHODOLOGY}

A survey method was implemented in this study using a closed-end questionnaire as a tool which was distributed to the respondents in order to gather all the required data. The questionnaire contains 14 items that represent all the variables assessed in this study. Among those 14 items, 3 indicators represent the variable of brand image, 4 indicators represent the variable of website quality, 3 indicators represent the variable of trust, and 4 indicators represent the variable of customer loyalty [1] [2] [4] [14] [16] [21] [23] [24]. Furthermore, a 7-Point Likert Scale method was also implemented as the measurement scale to assess the respondents' response toward the questionnaire, in which each respondent could show their response regarding each and every statement included in the questionnaire, which ranges between " 1 " as strong disagreement and "7" as strong agreement toward the statement.

Furthermore, all data which has been provided by the respondents, was assessed using PLS-SEM with SmartPLS version 3.3.2 as the software to analyze the data.

\section{ANALYSIS AND RESULTS}

As many as 350 respondents participated in this study, in which, those who were selected as the respondents are consumers who have visited and make purchasing activities from any Indonesian $\mathrm{C} 2 \mathrm{C}$ e-commerce websites at least twice a month for the past one year. Moreover, convenience sampling method was implemented in this study, in which, all questionnaires were electronically distributed to the respondents who match the sampling criteria set in this research. In regards with the result of data analyses regarding the profile of the respondents, it was revelaed that the majority of the respondents are male $(67.18 \%)$. Meanwhile, the response-rate of this study is $100 \%$ as all questionnaires were filled by the respondents and then returned to the author. However, after performing a thorough assessment toward the data, the author should omit a total of 27 questionnaires since those responses were incompletely filled in by the respondents. In the end, as many as 323 out of 350 questionanires were considered valid and could be processed further.

In using the PLS-SEM method to analyze the data, before determining whether all of the hypotheses proposed in this 
study were supported, the outer-model measurement analysis was required to be performed in advance with the purpose of determining whether all data included in this study was reliable and valid. Only after all of the criteria in the outer-model measurement analysis have been met, then the inner-model measurement analysis could be performed in order to determine the relationships among the variables in this study. There are several criteria which should be satisfied in order for all data to pass the outer model measurement, such as the value of AVE and factor loadings should be greater than 0.5, the square-root AVE of each latent construct should be higher than the variable's highest squared-correlation with any other variable (discriminant validity assessment using the fornell-larcker criterion). Meanwhile, the value of composite reliability of each variable also has to be greater than the minimum acceptance value of 0.7 [10] [11].

Only after all criteria or aspects in the outer-model analysis have been met, then the inner-model measurement analysis could be done, in which the inner-model measurement analysis itself should be conducted in order to test all of the hypotheses proposed in the beginning of this study.

\subsection{Outer-Model Measurement Analysis}

The outer-model measurement analysis was performed in order to assess whether or not all data in this study is valid and reliable. After analyzing and assessing the data, the author concludes that all criteria or aspects have been satisfied in the outer-model measurement analysis, since the factor loading of each indicator, the AVE, and the composite reliability of every variable have shown a value greater than 0.50 and 0.70 respectively. Moreover, the discriminant validity in this study has also been satisfied using the fornell-larcker criterion, the square root of AVE of each variable is higher than the variable's squared correlation with the other variables. Therefore, since all aspects or criteria within the outer-model measurement analysis have been satisfied, the inner-model measurement analysis could be further performed to reveal the relationships among the variables included in this study.

Table 1 Outer-Model Measurement Analysis (Validity Assessment)

\begin{tabular}{|c|c|c|c|c|c|}
\hline & BI & $W Q$ & $T R U$ & $C L$ & $A V E$ \\
\hline $\mathrm{BI}_{1}$ & 0.633 & & & & \multirow{3}{*}{0.511} \\
\hline $\mathrm{BI}_{3}$ & 0.733 & & & & \\
\hline $\mathrm{BI}_{4}$ & 0.771 & & & & \\
\hline $\mathrm{WQ}_{1}$ & & 0.798 & & & \multirow{4}{*}{0.547} \\
\hline $\mathrm{WQ}_{2}$ & & 0.658 & & & \\
\hline $\mathrm{WQ}_{3}$ & & 0.689 & & & \\
\hline $\mathrm{WQ}_{4}$ & & 0.731 & & & \\
\hline $\mathrm{TRU}_{1}$ & & & 0.760 & & \multirow{3}{*}{0.605} \\
\hline $\mathrm{TRU}_{2}$ & & & 0.838 & & \\
\hline $\mathrm{TRU}_{3}$ & & & 0.732 & & \\
\hline
\end{tabular}

\begin{tabular}{|l|l|l|l|l|l|}
\hline $\mathrm{CL}_{1}$ & & & & 0.641 & \multirow{2}{*}{0.520} \\
\cline { 1 - 4 } $\mathrm{CL}_{2}$ & & & & 0.818 & \multirow{2}{*}{0.752} \\
\cline { 1 - 4 } $\mathrm{CL}_{3}$ & & & & 0.736 & \\
\hline $\mathrm{CL}_{5}$ & & & & 0.00 \\
\hline
\end{tabular}

Table 2 Discriminant Validity Assessment

\begin{tabular}{|c|c|c|c|c|}
\hline & BI & WQ & TR & CL \\
\hline BI & $\mathbf{0 . 7 1 5}$ & & & \\
\hline WQ & 0.401 & $\mathbf{0 . 7 4 0}$ & & \\
\hline TR & 0.464 & 0.554 & $\mathbf{0 . 7 7 8}$ & \\
\hline CL & 0.594 & 0.388 & 0.528 & $\mathbf{0 . 7 2 1}$ \\
\hline
\end{tabular}

Table 3 Reliability Assessment

\begin{tabular}{|c|c|}
\hline Variables & Composite Reliability \\
\hline Brand Image & 0.757 \\
\hline Website Quality & 0.812 \\
\hline Trust & 0.821 \\
\hline Customer Loyalty & 0.827 \\
\hline
\end{tabular}

\subsection{Inner-Model Measurement Analysis and Hypotheses Testings}

Furthermore, after conducting the outer-model measurement analysis, the inner-model measurement analysis was further performed to assess the relationships among variables discussed in this study. Moreover, the inner-model measurement analysis also required to be performed in order to determine whether or not, to support or reject the hypotheses proposed in this study. The results of the inner-model measurement analysis are exhibited on Table 4, Table 5, and Table 6 respectively, while Table 7 presents the results of the hypothesis testings that have been conducted in this study.

Table 4 R-Squared Analysis

\begin{tabular}{|c|c|}
\hline Variables & R-Squared \\
\hline Trust & 0.314 \\
\hline Customer Loyalty & 0.307 \\
\hline
\end{tabular}

According to the result obtained after conducting the $R$ Squared analysis, it is known that customer loyalty has the R-squared value of 0.307 . In this case, it could be understood that $30.7 \%$ of variation in customer loyalty was explained by trust, while the rest of them, which is $69.3 \%$, was explained by the other variables, which are not discussed in this study. Furthermore, the result of data analysis also shows that trust has the R-Squared of 0.314 , which means that $31.4 \%$ of variation in trust variable was explained by brand image and website quality, while the remaining of $68.6 \%(100 \%-31.4 \%)$, was explained by the other variables out of this study. 
Table 5 Indirect-Effect Analysis

\begin{tabular}{|c|c|c|c|}
\hline Relationship & $\begin{array}{c}\text { Sample } \\
\text { Mean }\end{array}$ & $\begin{array}{c}\text { t- } \\
\text { Statistics }\end{array}$ & $\begin{array}{c}\text { p- } \\
\text { Values }\end{array}$ \\
\hline BI -> TRU & 0.246 & 2.271 & 0.024 \\
\hline WQ -> TRU & 0.572 & 4.194 & 0,000 \\
\hline TRU -> CL & 0.396 & 7.047 & 0,000 \\
\hline BI -> CL & 0.140 & 2.102 & 0.036 \\
\hline WQ -> CL & 0.227 & 3.346 & 0.001 \\
\hline
\end{tabular}

Table 6 Path-Coefficient Analysis

\begin{tabular}{|c|c|c|c|}
\hline Relationship & $\begin{array}{c}\text { Indirect } \\
\text { Effect }\end{array}$ & $\begin{array}{c}\text { t- } \\
\text { Statistics }\end{array}$ & $\begin{array}{c}\text { p- } \\
\text { Values }\end{array}$ \\
\hline $\begin{array}{c}\text { BI -> TRU -> } \\
\text { CL }\end{array}$ & 0.101 & 2.155 & 0.032 \\
\hline $\begin{array}{c}\text { WQ -> TRU-> } \\
\text { CL }\end{array}$ & 0.168 & 2.536 & 0.012 \\
\hline
\end{tabular}

Table 7 The Results of Hypothesis Testings

\begin{tabular}{|c|c|c|}
\hline \multicolumn{2}{|r|}{ Hypothesis } & Conclusions \\
\hline $\mathrm{H}_{1}$ & $\begin{array}{l}\text { Brand Image has a } \\
\text { positive effect on Trust }\end{array}$ & Supported \\
\hline $\mathrm{H}_{2}$ & $\begin{array}{l}\text { Website Quality has a } \\
\text { positive effect on Trust }\end{array}$ & Supported \\
\hline $\mathrm{H}_{3}$ & $\begin{array}{l}\text { Brand Image has a } \\
\text { positive effect on } \\
\text { Customer Loyalty }\end{array}$ & Supported \\
\hline $\mathrm{H}_{4}$ & $\begin{array}{l}\text { Website Quality has a } \\
\text { positive effect on } \\
\text { Customer Loyalty }\end{array}$ & Supported \\
\hline $\mathrm{H}_{5}$ & $\begin{array}{l}\text { Trust has a positive } \\
\text { effect on Customer } \\
\text { Loyalty }\end{array}$ & Supported \\
\hline $\mathrm{H}_{6}$ & $\begin{array}{l}\text { Brand Image has a } \\
\text { positive effect on } \\
\text { Customer Loyalty } \\
\text { through Trust }\end{array}$ & Supported \\
\hline $\mathrm{H}_{7}$ & $\begin{array}{l}\text { Website Quality has a } \\
\text { positive effect on } \\
\text { Customer Loyalty } \\
\text { through Trust }\end{array}$ & Supported \\
\hline
\end{tabular}

Based on the results of the hypothesis testings performed and presented in Table 7 , it could be seen that all hypotheses as proposed in the beginning of this study, were supported. The first hypothesis $\left(\mathrm{H}_{1}\right)$ proposed that brand image has a positive effect on trust. With a t-value of 2.271 , it means that this hypothesis was supported. The second hypothesis $\left(\mathrm{H}_{2}\right)$ proposed that website quality has a positive effect on trust. With a t-value of 4.194 , it means that the second hypothesis was supported as well. The third hypothesis $\left(\mathrm{H}_{3}\right)$ proposed that brand image has a positive effect on customer loyalty. With a t-value of 2.102 , it means that the third hypothesis was also supported. The fourth hypothesis $\left(\mathrm{H}_{4}\right)$ proposed that website quality has a positive effect on customer loyalty. With a t-value of 3.346, it means that the fourth hypothesis was also supported. The fifth hypothesis $\left(\mathrm{H}_{5}\right)$ proposed that trust has a positive effect on customer loyalty. With a t-value of 7.047, it means that the fifth hypothesis was also supported.

Moreover, in accordance with the results obtained from the mediaton analysis which was also performed in this study, the author could also conclude that trust was found to significantly mediate the effect of brand image on customer loyalty in a positive and partial manner, as the mediation value ( $\mathrm{t}$-value) of the relationship is greater than $1.96(2.155>1.96)$, while the direct effect of brand image on customer loyalty also turned out to be positive and significant. Furthermore, it can also be understood that trust also mediates the effect of website quality on customer loyalty in a partial and positive manner, as the mediation value (t-value) of the relationships is also greater than $1.96(2.536>1.96)$, while the direct effect of brand image on customer loyalty turned out to be positive and significant. Therefore, it could be concluded that the sixth $\left(\mathrm{H}_{6}\right)$ and seventh hypothesis $\left(\mathrm{H}_{7}\right)$ were also supported

\section{CONCLUSIONS AND SUGGESTIONS}

\subsection{Conclusions}

This study was conducted to analyze and determine whether brand image and website quality have a positive and significant effect on customer loyalty, both in a direct or indirect manner through trust. In accordance with the results obtained from data analysis, the conclusion is that both brand image and website quality have a significant and positive impact on customer loyalty, both directly and indirectly through trust. Such conclusion was obtained or created based on the fact that all hypotheses in this study were supported. The results of data analysis generated in this study indicate that customers' personal judgement and perception toward the image that a brand or company has, can play an integral part in affecting customers' level of loyalty toward the company. A positive or favourable-kind of image possessed by a company will most likely to increase people's or customers' trust toward the company, which in turn, will positively affect their loyalty toward the company.

On the other hand, the results obtained in this study also pointed out the importance and significance of website quality in affecting customer loyalty, both directly and indirectly through trust. Similar with brand image, website quality also turned out to be a factor or variable, which could positively affect trust and loyalty. This is mainly because in the e-commerce business, website has an incredibly integral role in mediating the relationship between the sellers and the buyers, in which, without the existence of website, it would be impossible for the buyer to interact with the seller, and vice versa. Therefore, an error-free and easy-to-use website with an exceptional and unmatched quality, could increase people's trust and 
willingness to conduct further transactions through the website, thus increasing their dependence and loyalty toward the website.

Therefore, the author may suggest the owner of companies running their business in the Indonesian e-commerce websites to take the precautionary and preventive acts regarding all activities that the company is about to conduct or execute, since those activities play a significant role in building and maintaining the company's brand image in people's mind. Once the company is doing an activity, which is negatively perceived by customers or public (either because the activity isn't conformed with the values believed by the public), then there will be a high possibility that the company's brand image will get tarnished. Furthermore, other than brand image, the author may suggest all companies enganging in the Indonesian ecommerce business to actively and periodically maintain their websites and systems, since all systems and websites owned or developed by the company are basically the lifeline of all operational activities conducted within the company, in which, an error that occur in one system could badly affect the other systems as well. Therefore, since there's no way that the seller and buyer could communicate one another other than through the website, company should pay extra and serious attention to the availability and usability of the website, in order to prevent unnecessary problems and also to ensure that both the seller and the buyer could communicate smoothly.

\subsection{Research Limitations and Direction for Future Research}

This study was executed and performed in the Indonesian e-commerce business, which may reduce the author's capability to generalize the conclusions and the results obtained in this study. Thus, it is highly recommended that future studies may perform an analysis regarding the model of this research in other industries. In addition, the sample size implemented in this research was 350 respondents, in which, this might hamper the generalizability regarding the results of this research, Therefore, the author would like to strongly suggest the prospective authors to conduct future research regarding this concept or model to add or expand the sample size in order to increase the generalizability of the results. Furthermore, this research was done to determine the impact of brand image and website quality on customer loyalty, both directly and indirectly through trust, in the Indonesian e-commerce business. Since the author believes that there are other variables that may affect customer loyalty, the author would like to suggest the prospective authors to add or include other additional variables in order to expand and increase the variability and uniqueness of the model.

\section{REFERENCES}

[1] Abror, A., Patrisia, D., Engriani, Y., Evanita, S., Yasri, Y. and Dastgir, S. (2019), "Service quality, religiosity, customer satisfaction, customer engagement and Islamic bank's customer loyalty", Journal of Islamic Marketing, Vol. 11 No. 6, pp. 1691-1705. https://doi.org/10.1108/JIMA-03-2019-0044

[2] Ahn, J., Wong, M.L. and Kwon, J. (2020), "Different role of hotel CSR activities in the formation of customers' brand loyalty", International Journal of Quality and Service Sciences, Vol. ahead-of-print No. ahead-of-print. https://doi.org/10.1108/IJQSS-02-20200028

[3] Baker, M.A. and Legendre, T.S. (2020), "Unintended negative consequences of loyalty programs: endowed vs earned loyalty", Journal of Services Marketing, Vol. ahead-of-print No. ahead-ofprint. https://doi.org/10.1108/JSM-02-2019-0089

[4] Bernarto, I., Wilson, N., \& Suryawan, I.N., Pengaruh Website Design Quality, Service Quality, Trust dan Satisfaction Terhadap Repurchase Intention (Studi Kasus: tokopedia.com), Jurnal Manajemen Indonesia, 19(1) (2019), 80-90.

[5] Choi, B. and Kim, H.S. (2020), "Customer-tocustomer interaction quality, promotion emotion, prevention emotion and attitudinal loyalty in mass services", Journal of Service Theory and Practice, Vol. 30 No. 3, pp. 257-276. https://doi.org/10.1108/JSTP08-2019-0172

[6] Csiszar, J. (2019, July 30). 10 Fastest-Growing Industries To Invest in This Year. Retrieved from https://www.gobankingrates.com/investing/stocks/faste st-growing-industries-to-invest-in/

[7] eCommerce-Indonesia (Core country: data based on in-depth analysis). Retrieved from https://www.statista.com/outlook/243/120/ecommerce/i ndonesia

[8] Foroudi, P., Cuomo, M.T. and Foroudi, M.M Continuance interaction intention in retailing: Relations between customer values, satisfaction, loyalty, and identification, Information Technology \& People, 33(4) (2019). 1303-1326. https://doi.org/10.1108/ITP-092018-0421

[9] Gligor, D., Bozkurt, S., Gölgeci, I. and Maloni, M.J. Does supply chain agility create customer value and satisfaction for loyal B2B business and B2C endcustomers? International Journal of Physical 
Distribution \& Logistics Management, 50 (7/8) (2020), 721-743. https://doi.org/10.1108/IJPDLM-01-20200004

[10] Hair, J. F., Ringle, C. M., \& Sarstedt, M., PLSSEM: Indeed a Silver Bullet. The Journal of Marketing Theory and Practice, 19(2) (2011), 139-151.

[11] Henseler, J., Ringle, C. M., \& Sinkovics, R. R. The use of partial least square path modeling in international marketing. Advances in International Marketing, 20 (2009), 277-319.

[12] Keni, K., Oktora, F. and Wilson, N. The Impact of Destination Image and Perceived Quality on Tourist Loyalty in the Indonesian Tourism Industry. In Proceedings of the 7th International Conference on Entrepreneurship and Business Management - Volume 1: ICEBM Untar, (2018). pp. 67-75. $10.5220 / 0008488300670075$

[13] Kusumawati, A. and Rahayu, K.S. The effect of experience quality on customer perceived value and customer satisfaction and its impact on customer loyalty, The TQM Journal, 32(6) (2020), 1525-1540. https://doi.org/10.1108/TQM-05-2019-0150

[14] Moon, J.Y. Corporate Image Effects on Consumers' Evaluation of Brand Trust and Brand Affect, Journal of Global Academy of Marketing Science, 17(3) (2007), 21-37

[15] Quach, S., Thaichon, P., Roberts, R.E. and Weaven, S. Loyalty layers, expectations and the role of knowledge, Marketing Intelligence \& Planning, Vol. ahead-of-print No. ahead-of-print (2020). https://doi.org/10.1108/MIP-09-2019-0489

[16] Song, H.J., Wang, J.H., \& Han, H.S. Effect of image, satisfaction, trust, love, and respect on loyalty formation for name-brand coffee shops, International Journal of Hospitality Management, 79 (2019), 50-59.

[17] Wilson, N. The Impact of Perceived Usefulness and Perceived Ease-of-Use toward Repurchase Intention in the Indonesian E-Commerce Industry, Jurnal Manajemen Indonesia. 19 (3) (2019), 241-249. https://doi.org/10.25124/jmi.v19i3.2412

[18] Wilson, N. The Impact of Service Quality and Brand Image Toward Customer Loyalty in The Indonesian Airlines Industry, Jurnal Manajemen Indonesia. 18 (3) (2018), 222-234. https://doi.org/10.25124/jmi.v18i3.1734

[19] Wilson, N., \& Christella, R. An Empirical Research of Factors Affecting Customer Satisfaction: A Case of the Indonesian E-Commerce Industry, DeReMa
Jurnal Manajemen, 14(1) (2019), 21-44. http://dx.doi.org/10.19166/derema.v14i1.1108

[20] Wilson, N., \& Makmud, S.T. The Impact Of Brand Evaluation, Satisfaction, Brand Relationship And Trust To Brand Loyalty: A Case Study Of The Indonesian Smartphone Industry, Jurnal Muara Ilmu Sosial, Humaniora, dan Seni, 2(2) (2018), 633-649.

[21] Wilson, N., and Keni, K. Pengaruh Website Design Quality dan Kualitas Jasa Terhadap Repurchase Intention: Variabel Trust Sebagai Variabel Mediasi, Jurnal Manajemen dan Pemasaran Jasa, 11(2) (2018), 291-310. http://dx.doi.org/10.25105/jmpj.v11i2.3006

[22] Wilson, N., Keni, K., and Tan, P.H.P. The Effect of Website Design Quality and Service Quality on Repurchase Intention in the E-commerce Industry: A Cross-Continental Analysis, Gadjah Mada International Journal of Business, 21(2) (2019), 187-222. https://doi.org/10.22146/gamaijb.33665

[23] Zhou, T., Lu, Y., dan Wang, B. The Relative Importance of Website Design Quality and Service Quality in Determining Consumers' Online Repurchase Behavior. Information Systems Management, 26 (2009), 327-337.

[24] Zhu, R., Srivastava, A. and Sutanto, J. Privacydeprived e-commerce: the efficacy of consumer privacy policies on China's e-commerce websites from a legal perspective", Information Technology \& People, 33(6) (2020), 1601-1626. https://doi.org/10.1108/ITP-032019-0117 